\title{
Digital ischaemia and HCV, a vasculitis of uncertain aetiology
}

\author{
Cristina Peña Arce, ${ }^{1}$ Norberto Ortego Centeno, ${ }^{2}$ Daniel Sánchez Cano, ${ }^{2}$ \\ Carmen Pérez López ${ }^{3}$
}

'Internal Medicine, Mostoles University Hospital, Mostoles, Spain

${ }^{2}$ Department of Systemic Diseases, Health Technology Park, Granada, Spain ${ }^{3}$ Internal Medicine, University Hospital Virgen de la Victoria, Malaga, Spain

\section{Correspondence to}

Dr Cristina Peña Arce, cristinapenarce@icloud.com

Accepted 24 May 2019

\section{DESCRIPTION}

A 45-year-old woman with unmonitored $C$ virus, a former cocaine user, visited the emergency department after a change in the colour of her fingers, accompanied by an intense pain caused by coming into contact with cold water (figure 1). Bilateral ulnar and radial pulses were present and equal.

The patient did not show increased acute phase reactants, and both renal function and sediment were normal. A chest X-ray and transthoracic echocardiography showed no findings, while an EKG revealed a sinus rhythm. The patient had only slightly elevated rheumatoid factor (RF) concentrations with normal anti-cyclic citrullinated peptide, cryoglobulins, serum electrophoresis and immunofixation, antiphospholipid antibodies and complement (C3 and $\mathrm{C} 4)$. Urinary samples tested negative for cocaine. Serological results were positive for hepatitis $\mathrm{C}$ virus (HCV; genotype 1a) with a high level of viremia (RNA 2450000 copies $/ \mathrm{mL}$ ), and a FibroScan revealed a value of $15.4 \mathrm{kPa}$.
Steroid pulses, plasmapheresis, Rituximab, prostaglandin infusions, an anticoagulant dose of heparin, antiplatelet therapy and morphine perfusion were administrated to the patient.

Given the presence of active $\mathrm{C}$ virus, isolated positive RF, negative cryoglobulins and regular complement, vasculitis due to HCV was considered. It was then decided to administer an antiviral treatment. The patient's appearance on discharge can be seen in figure 2 .

We put forward a case of subacute digital ischaemia suggestive of vasculitis, as its etymological origin was hard to define. Cryoglobulinemic vasculitis was our primary hypothesis. Mixed cryoglobulins (type II to III) together with RF activity and complement form immune complexes, resulting in vascular damage. The skin is frequently involved. This kind of pathology is in most cases related to an underlying disease (HCV in 70\%-90\% of cases). The diagnosis is made on a compatible clinical presentation, analytical data (RF and low $\mathrm{C} 4)$ and

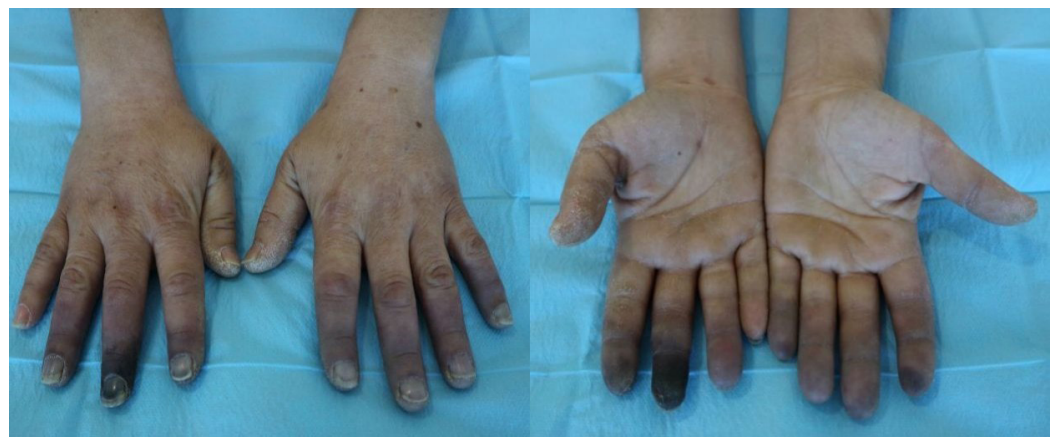

Figure 1 Digital ischaemia from the second to fifth fingers of both hands. Dry gangrene in the third finger of the right hand. Palmar hyperkeratosis injuries. Coldness starting from the distal interphalangeal. Symmetrical radial pulse.

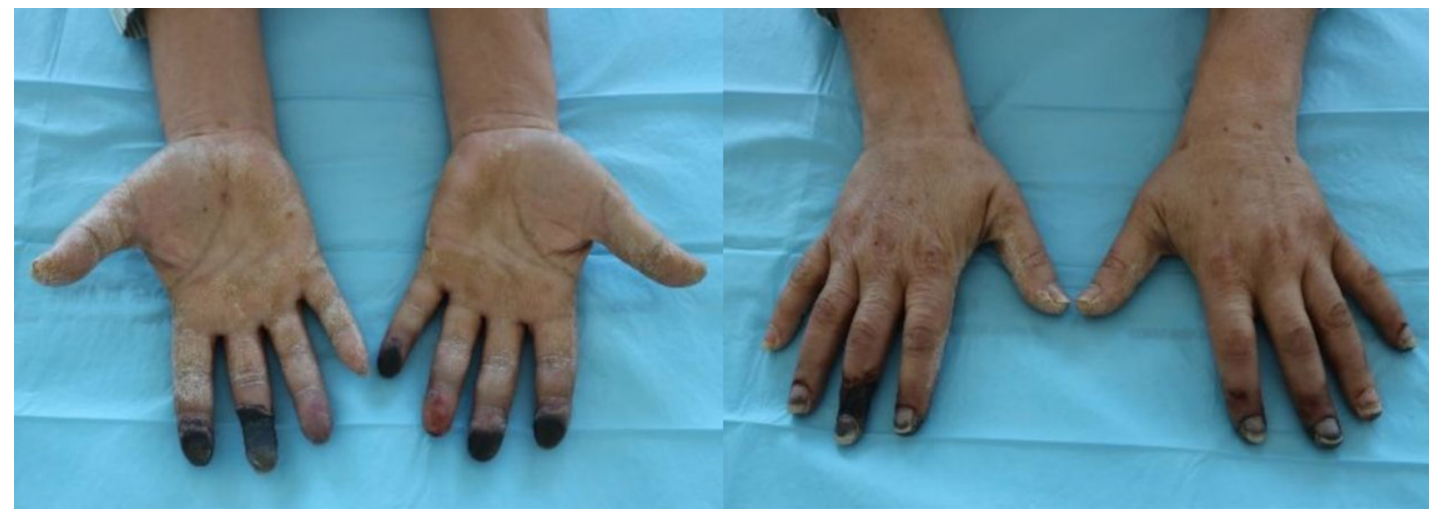

Figure 2 Evolution after treatment. Dry gangrene persists in the second and third fingers of the right hand as well as the second, third, and fifth fingers of the left hand. 
the presence of circulating cryoglobulins. It should be noted that these immunoglobulins precipitate (in a reversible way) at low temperatures. Consequently, extracting the blood is rather troublesome (high rate of false negatives). ${ }^{1}$ We could not confirm the presence of cryoglobulins; however, the patient did not show indirect evidence of the formation of immune complexes (regular complement). Cryofibrinogen might be another cause of digital ischaemia in HCV patients (strongly associated with cryoglobulins). However, our patient tested negative.

Cocaine can produce vasculitis-like multisystemic alterations as well, especially of the antineutrophil cytoplasmic antibodies (ANCA) type (very high titres) with an atypical pattern. Patients who consume cocaine might test positive for both myeloperoxidase and proteinase 3 . The addition of levamisole (an adulterant

\section{Learning points}

Ninety percent of cryoglobulinemic vasculitis is related to underlying disease, with hepatitis $\mathrm{C}$ virus (HCV) the most common. Patients show indirect evidence of the formation of immune complexes (complement consumption and increased rheumatoid factor). Negative results for circulant cryoglobulins do not rule out their diagnosis.

- HCV can lead to multiple immunomediated systemic manifestations along with the presence of antibodies, which makes it indistinguishable from an autoimmune disease.

- Cocaine can produce vasculitis-like multisystemic alterations, especially those of the antineutrophil cytoplasmic antibodies pattern. The absence of toxins in the urine does not eliminate that entity. of cocaine) can cause acral ischaemia and cutaneous ulcers too. ${ }^{2}$ In the present case, although the presence of negative toxins in the urine did not rule it out (drugs can induce immunomediation long after their consumption), the lack of positive ANCA, and the fact that the patient repeatedly denied taking narcotics, led us to dismiss that possibility.

Consequently, vasculitis due to HCV was our final diagnosis. This virus is extremely lymphotropic and immunogenic. It can generate extrahepatic affection on the autoimmune mechanism, giving rise to all kinds of systemic symptoms with isolated nonspecific antibodies (increased RF in our patient). ${ }^{3}$

Contributors All authors listed contributed sufficiently to the project to be included as authors, and all those who are qualified to be authors are listed in the author byline. CPA contributed to discuss planning, reporting, follow-up of the case, conception and design, acquisition of informed consent, writing the case and cover letter. CPL contributed to discuss planning, reporting and follow-up of the case.

DSC contributed to discuss planning, reporting, follow up of the case and take the pictures. NOC contributed to discuss planning, reporting, follow up of the case and write and correct the case.

Funding The authors have not declared a specific grant for this research from any funding agency in the public, commercial or not-for-profit sectors.

Competing interests None declared.

Patient consent for publication Obtained.

Provenance and peer review Not commissioned; externally peer reviewed.

\section{REFERENCES}

1 Ramos-Casals M, Stone JH, Cid MC, et al. The cryoglobulinaemias. Lancet 2012:379:348-60.

2 Subesinghe S, van Leuven S, Yalakki L, et al. Cocaine and ANCA associated vasculitislike syndromes - A case series. Autoimmun Rev 2018;17:73-7.

3 Ragab G, Hussein MA. Vasculitic syndromes in hepatitis C virus: A review. J Adv Res 2017:8:99-111.

Copyright 2019 BMJ Publishing Group. All rights reserved. For permission to reuse any of this content visit

https://www.bmj.com/company/products-services/rights-and-licensing/permissions/

BMJ Case Report Fellows may re-use this article for personal use and teaching without any further permission.

Become a Fellow of BMJ Case Reports today and you can:

- Submit as many cases as you like

- Enjoy fast sympathetic peer review and rapid publication of accepted articles

- Access all the published articles

- Re-use any of the published material for personal use and teaching without further permission

Customer Service

If you have any further queries about your subscription, please contact our customer services team on +44 (0) 2071111105 or via email at support@bmj.com.

Visit casereports.bmj.com for more articles like this and to become a Fellow 